\title{
Synthesis, Characterization and X-Ray Crystal Structures of cis-Dioxomolybdenum(VI) Complexes of Similar Tridentate Aroylhydrazone Schiff Bases with Catalytic Epoxidation Activity
}

\author{
Qing Liu, ${ }^{1}$ Jiahui Lin, ${ }^{1}$ Juan Liu, ${ }^{1}$ Wu Chen ${ }^{1,2}$ and Yongming Cui ${ }^{3 * *}$ \\ ${ }^{1}$ School of Textile Science and Engineering, Wuhan Textile University, Wuhan 430073, P. R. China \\ ${ }^{2}$ Ministry of Education Key Laboratory for Textile Fibers and Products, Wuhan Textile University, Wuhan 430073, P. R. China \\ ${ }^{3}$ School of Environmental Engineering, Wuhan Textile University, Wuhan 430073, P. R. China \\ * Corresponding author: E-mail: cym981248@sohu.com
}

Received: 14-11-2015

\begin{abstract}
Two new cis-dioxomolybdenum(VI) complexes with general formula $\left[\mathrm{MoO}_{2} \mathrm{~L}(\mathrm{MeOH})\right]$, where $\mathrm{L}=\mathrm{L}^{1}=N^{\prime}-(3,5$-dibromo2-hydroxybenzylidene)-4-trifluoromethylbenzohydrazide for complex 1, and $\mathrm{L}=\mathrm{L}^{2}=N^{\prime}$-(3-bromo-5-chloro-2-hydroxybenzylidene)-4-trifluoromethylbenzohydrazide for complex $\mathbf{2}$, have been synthesized and fully characterized on the basis of elemental analysis, FT-IR, molar conductivity, and electronic spectra. The complexes are also characterized by single crystal X-ray diffraction. The complexes have distorted octahedral structures in which the aroylhydrazones behave as dianionic ligands. It is also revealed from the crystal structures that the $\mathrm{Mo}(\mathrm{VI})$ center adopts $\mathrm{NO}_{5}$ donor environment, and the octahedral coordination is furnished by two oxido groups and oxygen atoms of neutral methanol molecules. The catalytic properties were investigated for epoxidation of cyclooctene using aqueous tert-butyl hydroperoxide as the oxidant.
\end{abstract}

Keywords: Dioxomolybdenum(VI); Aroylhydrazone; Schiff base; X-ray crystal structure; Catalytic epoxidation activity

\section{Introduction}

In the last 60 years, Schiff base ligands and their transition metal complexes have attracted considerable attention, not only for their facile synthesis, but also for potential biological, catalytic and industrial applications. ${ }^{1}$ In recent years, vanadium complexes with hydrazones have been widely studied, either from the structural or catalytic aspect. ${ }^{2}$ As we know, catalytic epoxidation of olefins is an important reaction in organic synthesis. Many transition metal complexes are active catalysts for this process. ${ }^{3}$ Yet, among the complexes, molybdenum complexes have a unique place in coordination chemistry and have displayed very high catalytic activities in the oxidation of olefins and sulfides. ${ }^{4}$ In the present work, two similar aroylhydrazone Schiff bases, $N$ '-(3,5-dibromo-2hydroxybenzylidene)-4-trifluoromethylbenzohydrazide $\left(\mathrm{H}_{2} \mathrm{~L}^{1}\right)$ and $N^{\prime}$-(3-bromo-5-chloro-2-hydroxybenzylidene)-4-trifluoromethylbenzohydrazide $\left(\mathrm{H}_{2} \mathrm{~L}^{2}\right)$, were prepa- red and used to prepare dioxomolybdemum(VI) complexes with $\left[\mathrm{MoO}_{2}(\mathrm{acac})_{2}\right]$ in methanol. The catalytic properties were investigated for epoxidation of cyclooctene using aqueous tert-butyl hydroperoxide as the oxidant.

\section{Experimental}

\section{1. Materials and Methods}

4-Trifluoromethylbenzohydrazide was prepared as described in the literature. ${ }^{5}$ 3,5-Dibromosalicylaldehyde and 3-bromo-5-chlorosalicylaldehyde were purchased from Alfa Aesar and used as received. $\left[\mathrm{MoO}_{2}(\mathrm{acac})_{2}\right]$ was prepared as described in the literature. ${ }^{6}$ Reagent grade solvents were used as received. Microanalyses of the complexes were performed with a Vario EL III CHNOS elemental analyzer. Infrared spectra were recorded as $\mathrm{KBr}$ pellets with an FTS-40 spectrophotometer. Electronic spectra were recorded on a Lambda 900 spectrometer. The 
catalytic reactions were followed by gas chromatography on an Agilent 6890A chromatograph equipped with an FID detector and a DB5-MS capillary column (30 $\mathrm{m} \times$ $0.32 \mathrm{~mm}, 0.25 \mu \mathrm{m})$. Molar conductance measurements were made by means of a Metrohm 712 conductometer in acetonitrile. ${ }^{1} \mathrm{H}$ NMR spectra were recorded on a Bruker spectrometer at $300 \mathrm{MHz}$.

\section{2. Synthesis of the Aroylhydrazone Schiff Bases}

The aroylhydrazone Schiff bases $\mathrm{H}_{2} \mathrm{~L}^{1}$ and $\mathrm{H}_{2} \mathrm{~L}^{2}$ were synthesized in a similar way by refluxing a methanolic solution $(30 \mathrm{~mL})$ of 4-trifluoromethylbenzohydrazide $(10 \mathrm{mmol}$, $2.04 \mathrm{~g}$ ) with 3,5-dibromosalicylaldehyde (10 mmol, $2.80 \mathrm{~g})$ and 3-bromo-5-chlorosalicylaldehyde (10 mmol, $2.35 \mathrm{~g})$, respectively. Reflux was continued for $1 \mathrm{~h}$ in oil bath during which a solid compound separated. It was filtered and washed with cold methanol. The crude product was recrystallized from methanol and dried over anhydrous $\mathrm{CaCl}_{2}$.

$\mathrm{H}_{2} \mathrm{~L}^{1}$ : Yield: $3.73 \mathrm{~g}(80 \%)$. IR data ( $\mathrm{KBr}$ pellet, $\left.\mathrm{cm}^{-1}\right): 3351 v(\mathrm{O}-\mathrm{H}), 3218 v(\mathrm{~N}-\mathrm{H}), 1653 v(\mathrm{C}=\mathrm{O}), 1615$ $v(\mathrm{C}=\mathrm{N})$. UV-Vis data in methanol $(\mathrm{nm}): 283,362,425$. Analysis: Found: C 38.50, H 2.02, N 5.93\%. Calculated for $\mathrm{C}_{15} \mathrm{H}_{9} \mathrm{Br}_{2} \mathrm{~F}_{3} \mathrm{~N}_{2} \mathrm{O}_{2}$ : C 38.66, $\mathrm{H} 1.95, \mathrm{~N} 6.01 \%$. ${ }^{1} \mathrm{H}$ NMR (300 MHz, $d^{6}$-DMSO): $\delta 12.13(\mathrm{~s}, 1 \mathrm{H}, \mathrm{OH}), 11.22(\mathrm{~s}, 1 \mathrm{H}$, $\mathrm{NH}), 8.71(\mathrm{~s}, 1 \mathrm{H}, \mathrm{CH}=\mathrm{N}), 7.92(\mathrm{~d}, 2 \mathrm{H}, \mathrm{ArH}), 7.72-7.85$ (m, 4H, ArH).

$\mathrm{H}_{2} \mathrm{~L}^{2}$ : Yield: $3.85 \mathrm{~g}(91 \%)$. IR data ( $\mathrm{KBr}$ pellet, $\left.\mathrm{cm}^{-1}\right): 3347 v(\mathrm{O}-\mathrm{H}), 3227 v(\mathrm{~N}-\mathrm{H}), 1655 v(\mathrm{C}=\mathrm{O}), 1617$ $v(\mathrm{C}=\mathrm{N})$. UV-Vis data in methanol $(\mathrm{nm}): 281,360,425$.
Analysis: Found: C 42.91, H 2.23, N 6.55\%. Calculated for $\mathrm{C}_{15} \mathrm{H}_{9} \mathrm{BrClF}_{3} \mathrm{~N}_{2} \mathrm{O}_{2}: \mathrm{C} 42.73, \mathrm{H} 2.15, \mathrm{~N} 6.64 \% .{ }^{1} \mathrm{H}$ NMR (300 MHz, $d^{6}$-DMSO): $\delta 12.37(\mathrm{~s}, 1 \mathrm{H}, \mathrm{OH}), 11.15$ (s, 1H, NH), $8.72(\mathrm{~s}, 1 \mathrm{H}, \mathrm{CH}=\mathrm{N}), 7.92$ (d, 2H, ArH), 7.83 (d, 2H, ArH), 7.49-7.56 (m, 2H, ArH).

\section{3. Preparation of the Complexes}

The complexes $\left[\mathrm{MoO}_{2} \mathrm{~L}^{1}(\mathrm{MeOH})\right]$ (1) and [Mo$\left.\mathrm{O}_{2} \mathrm{~L}^{2}(\mathrm{MeOH})\right](2)$ were prepared in a similar way by refluxing a methanolic solution $(30 \mathrm{ml})$ of $\left[\mathrm{MoO}_{2}(\mathrm{acac})_{2}\right]$ (1.0 mmol, $0.33 \mathrm{~g}$ ) with methanolic solutions of $\mathrm{H}_{2} \mathrm{~L}^{1}(1.0$ mmol, $0.47 \mathrm{~g})$ and $\mathrm{H}_{2} \mathrm{~L}^{2}(1.0 \mathrm{mmol}, 0.42 \mathrm{~g})$, respectively. Initially on mixing the two components immediately an orange yellow color was observed. The mixture was refluxed for $1 \mathrm{~h}$. Orange crystals were formed during slow evaporation of the reaction mixture. The resulting orange crystals were filtered, washed with cold methanol and dried over anhydrous $\mathrm{CaCl}_{2}$.

[ $\left.\mathrm{MoO}_{2} \mathrm{~L}^{1}(\mathrm{MeOH})\right]$ (1): Yield: $0.40 \mathrm{~g}(69 \%)$. IR data $\left(\mathrm{KBr}\right.$ pellet, $\left.\mathrm{cm}^{-1}\right): 3461 v(\mathrm{O}-\mathrm{H}), 1606 v(\mathrm{C}=\mathrm{N}), 1326$ $v\left(\mathrm{C}-\mathrm{O}_{\text {phenolate }}\right), 1135 v(\mathrm{~N}-\mathrm{N}), 948 v_{\text {asym }}\left(\right.$ cis $\left.-\mathrm{MoO}_{2}\right) .852$ $v_{\text {asym }}\left(\right.$ cis $\left.-\mathrm{MoO}_{2}\right)$. UV-Vis data in acetonitrile (nm): 293, 305,335 , 407. Molar conductance $\left(10^{-3} \mathrm{M}\right.$, acetonitrile): $25 \Omega^{-1} \cdot \mathrm{cm}^{2} \cdot \mathrm{mol}^{-1}$. Analysis: Found: C 33.32, H 2.03, N 4.75\%. Calculated for $\mathrm{C}_{16} \mathrm{H}_{11} \mathrm{BrClF}_{3} \mathrm{MoN}_{2} \mathrm{O}_{5}$ : C 33.16, H 1.91, N 4.83\%. ${ }^{1} \mathrm{H}$ NMR (300 MHz, $d^{6}$-DMSO): $\delta 10.56$ $(\mathrm{s}, 1 \mathrm{H}, \mathrm{OH}), 8.37(\mathrm{~s}, 1 \mathrm{H}, \mathrm{CH}=\mathrm{N}), 8.11(d, 2 \mathrm{H}, \mathrm{ArH}), 7.63-$ 7.85 (m, 4H, $\mathrm{ArH}), 3.35$ (s, 3H, $\left.\mathrm{CH}_{3}\right)$.

[ $\left.\mathrm{MoO}_{2} \mathrm{~L}^{2}(\mathrm{MeOH})\right](2)$ : Yield: $0.35 \mathrm{~g}(56 \%)$. IR data $\left(\mathrm{KBr}\right.$ pellet, $\left.\mathrm{cm}^{-1}\right): 3450 v(\mathrm{O}-\mathrm{H}), 1605 v(\mathrm{C}=\mathrm{N}), 1324$

Table 1. Crystallographic Data for the Complexes

\begin{tabular}{lll}
\hline & $\mathbf{1}$ & $\mathbf{2}$ \\
\hline Empirical formula & $\mathrm{C}_{16} \mathrm{H}_{11} \mathrm{Br}_{2} \mathrm{~F}_{3} \mathrm{MoN}_{2} \mathrm{O}_{5}$ & $\mathrm{C}_{16} \mathrm{H}_{11} \mathrm{BrClF}_{3} \mathrm{MoN}_{2} \mathrm{O}_{5}$ \\
Formula weight & 624.03 & 579.57 \\
Crystal system & monoclinic & monoclinic \\
Space group & $P 2_{1} / c$ & $P 2_{1} / c$ \\
$a[\AA]$ & $14.9598(10)$ & $14.8713(9)$ \\
$b[\AA]$ & $7.7777(5)$ & $7.7280(6)$ \\
$c[\AA]$ & $17.2464(10)$ & $17.2061(11)$ \\
$\beta\left[^{\circ}\right]$ & $92.323(2)$ & $93.017(2)$ \\
$V\left[\AA^{3}\right]$ & $2005.0(2)$ & $1974.7(2)$ \\
$Z$ & 4 & 4 \\
$\rho_{\text {calcd. }}$ [g cm & \\
$\mu\left[\mathrm{m}^{-1}\right]$ & 2.067 & 1.949 \\
$F(000)$ & 4.698 & 2.881 \\
Measured reflections & 1200 & 1128 \\
Independent reflections & 11309 & 10411 \\
Observed reflections $(I>2 \sigma(I))$ & 3724 & 3671 \\
Parameters & 2529 & 2608 \\
Data completeness & 265 & 266 \\
Final $R$ indices $[I>2 \sigma(I)]$ & 1.023 & 1.017 \\
$R$ indices (all data) & $0.0444,0.0905$ & $0.0406,0.0936$ \\
Goodness-of-fit on $F^{2}$ & $0.0790,0.1057$ & $0.0669,0.1043$ \\
Largest difference in peak and hole $\left(\mathrm{e} \AA^{-3}\right)$ & 1.023 & 1.017 \\
\hline
\end{tabular}

Liu et al.: Synthesis, Characterization and X-Ray Crystal Structures $\quad$... 
$v\left(\mathrm{C}-\mathrm{O}_{\text {phenolate }}\right), 1132 v(\mathrm{~N}-\mathrm{N}), 947 v_{\text {sym }}\left(\right.$ cis $\left.-\mathrm{MoO}_{2}\right), 853$ $v_{\text {asym }}\left(\right.$ cis- $\left.\mathrm{MoO}_{2}\right)$. UV-Vis data in acetonitrile $(\mathrm{nm}): 293$, 304, 325, 409. Molar conductance $\left(10^{-3} \mathrm{M}\right.$, acetonitrile): $23 \Omega^{-1} \cdot \mathrm{cm}^{2} \cdot \mathrm{mol}^{-1}$. Analysis: Found: C $30.67, \mathrm{H} 1.85, \mathrm{~N}$ 4.56\%. Calculated for $\mathrm{C}_{16} \mathrm{H}_{11} \mathrm{Br}_{2} \mathrm{~F}_{3} \mathrm{MoN}_{2} \mathrm{O}_{5}$ : C 30.80, H 1.78, N 4.49\%. ${ }^{1} \mathrm{H}$ NMR (300 MHz, $d^{6}$-DMSO): $\delta 10.47$ (s, 1H, OH), 8.37 (s, 1H, CH=N), $8.11(\mathrm{~d}, 2 \mathrm{H}, \operatorname{Ar} H), 7.69$ (d, 2H, ArH), 7.50 (s, 1H, ArH), 7.56 (s, 1H, ArH), 3.35 (s, $3 \mathrm{H}, \mathrm{CH}_{3}$ ).

\section{4. Crystal Structure Determination}

Data were collected on a Bruker SMART 1000 CCD area diffractometer using a graphite monochromator Mo $\mathrm{K} \alpha$ radiation $(\lambda=0.71073 \AA$ ) at $298(2) \mathrm{K}$. The data were corrected with SADABS programs and refined on $F^{2}$ with Siemens SHELXL software. ${ }^{7}$ The structures were solved by direct methods and difference Fourier syntheses. All non-hydrogen atoms were refined anisotropically. The methanol hydrogen atoms were located from difference Fourier maps and refined isotropically, with $\mathrm{O}-\mathrm{H}$ distances restrained to $0.85(1) \AA$. The remaining hydrogen atoms were placed in calculated positions and included in the last cycles of refinement. Crystal data and details of the data collection and refinement are listed in Table 1. Selected coordinate bond lengths and angles are listed in Table 2.

\section{5. Catalytic Epoxidation Process}

A mixture of cyclooctene $(2.76 \mathrm{~mL}, 20 \mathrm{mmol})$, acetophenone (internal reference) and the complexes as catalysts $(0.05 \mathrm{mmol})$ was stirred and heated up to $80^{\circ} \mathrm{C}$ before addition of aqueous tert-butyl hydroperoxide (TBHP; $70 \% \mathrm{w} / \mathrm{w}, 5.48 \mathrm{~mL}, 40 \mathrm{mmol}$ ). The mixture is initially an emulsion, but two phases become clearly visible as the reaction progresses, a colorless aqueous one and a yellowish organic one. The reaction was monitored for $5 \mathrm{~h}$ with
Table 2. Selected Bond Lengths $(\AA)$ and Angles $\left(^{\circ}\right)$ for the Complexes

\begin{tabular}{lcr}
\hline & $\mathbf{1}$ & \multicolumn{1}{c}{$\mathbf{2}$} \\
\hline Mo1-O1 & $1.930(4)$ & $1.923(3)$ \\
Mo1-O2 & $2.004(4)$ & $2.002(3)$ \\
Mo1-O3 & $1.680(4)$ & $1.681(4)$ \\
Mo1-O4 & $2.321(4)$ & $2.318(3)$ \\
Mo1-O5 & $1.699(3)$ & $1.688(3)$ \\
Mo1-N1 & $2.262(4)$ & $2.257(3)$ \\
O3-Mo1-O5 & $105.6(2)$ & $105.66(16)$ \\
O3-Mo1-O1 & $98.6(2)$ & $98.97(18)$ \\
O5-Mo1-O1 & $103.24(18)$ & $103.11(14)$ \\
O3-Mo1-O2 & $95.9(2)$ & $96.00(17)$ \\
O5-Mo1-O2 & $98.37(17)$ & $98.08(13)$ \\
O1-Mo1-O2 & $149.54(15)$ & $149.57(12)$ \\
O3-Mo1-N1 & $94.44(17)$ & $94.44(14)$ \\
O5-Mo1-N1 & $158.47(17)$ & $158.32(14)$ \\
O1-Mo1-N1 & $80.88(15)$ & $81.18(12)$ \\
O2-Mo1-N1 & $71.39(15)$ & $71.34(11)$ \\
O3-Mo1-O4 & $169.59(15)$ & $169.78(13)$ \\
O5-Mo1-O4 & $84.13(16)$ & $83.86(13)$ \\
O1-Mo1-O4 & $82.32(16)$ & $82.10(13)$ \\
O2-Mo1-O4 & $78.80(15)$ & $78.70(12)$ \\
N1-Mo1-O4 & $75.42(13)$ & $75.63(11)$ \\
\hline
\end{tabular}

withdrawal and analysis of organic phase aliquots $(0.1 \mathrm{~m}$ L) at required times. Each withdrawn sample was mixed with $2 \mathrm{~mL}$ of diethylether, treated with a small quantity of $\mathrm{MnO}_{2}$ and then filtered through silica and analyzed by GC.

\section{Results and Discussion}

\section{1. Synthesis}

The aroylhydrazone Schiff bases and their complexes were synthesized in a facile and analogous way (Scheme 1).<smiles>[X]c1cc(Br)c(O)c(C=O)c1</smiles>

Scheme 1. The synthesis of the aroylhydrazone Schiff bases and the complexes 
The aroylhydrazone Schiff bases act as tridentate dianionic ONO donor ligands toward the $\mathrm{MoO}_{2}{ }^{2+}$ core. Both $\mathrm{Mo}(\mathrm{VI})$ complexes were obtained from a refluxing mixture of the respective ligand and $\left[\mathrm{MoO}_{2}(\mathrm{acac})_{2}\right]$ in 1:1 molar proportion in methanol. Complexes of the general formula $\left[\mathrm{MoO}_{2} \mathrm{~L}(\mathrm{MeOH})\right]$ were isolated as orange single crystals from the reaction mixture by slow evaporation at room temperature. The complexes are stable at room temperature and are found to be fairly soluble in most of the common organic solvents such as methanol, ethanol, acetonitrile, DMF and DMSO. The low molar solution conductance of the complexes in acetonitrile, indicates the complexes have non-electrolyte behavior.

\section{2. IR and Electronic Spectra}

IR spectra of the aroylhydrazone Schiff bases show bands at about $3220 \mathrm{~cm}^{-1}$ for $v(\mathrm{~N}-\mathrm{H}), 3350 \mathrm{~cm}^{-1}$ for $v(\mathrm{O}-\mathrm{H})$, and $1654 \mathrm{~cm}^{-1}$ for $v(\mathrm{C}=\mathrm{O}) .{ }^{8}$ The peaks attributed to $v(\mathrm{~N}-\mathrm{H})$ and $v(\mathrm{C}=\mathrm{O})$ are absent in the spectra of the complexes as each ligand binds in dianionic form resulting in losing proton from carbohydrazide group. Strong bands observed at $1606 \mathrm{~cm}^{-1}$ for 1 and $1605 \mathrm{~cm}^{-1}$ for 2 are attributed to $v(\mathrm{C}=\mathrm{N})$, which are located at lower frequencies as compared to the free aroylhydrazone Schiff bases, viz. $1615 \mathrm{~cm}^{-1}$ for $\mathrm{H}_{2} \mathrm{~L}^{1}$ and $1617 \mathrm{~cm}^{-1}$ for $\mathrm{H}_{2} \mathrm{~L}^{2}{ }^{2}$. The two molybdenum complexes exhibit two characteristic bands at $948 \mathrm{~cm}^{-1}$ and $852 \mathrm{~cm}^{-1}$ for asymmetric and symmetric stretching of cis- $\mathrm{MoO}_{2}{ }^{2+}$ core, respectively. ${ }^{10}$ Due to IR data, it is obvious that ligands exist in the uncoordinated form in keto-amino tautomer form and in the complexes in imino-enol tautomeric form. This is not uncommon in the coordination of aroylhydrazone Schiff bases. ${ }^{11}$

Electronic spectra of the complexes recorded in acetonitrile solution display strong and medium absorption bands centered at 408 and $293 \mathrm{~nm}$. These peaks are assigned as charge transfer transitions of the type $\mathrm{N}(p \pi)-\mathrm{Mo}(d \pi)$ and $\mathrm{O}(p \pi)-\mathrm{Mo}(d \pi)$, respectively, ${ }^{9}$ as the ligand based orbitals are either $\mathrm{N}$ or $\mathrm{O}$ donor types. The slight change of $\lambda_{\text {max }}$ values within each set of peaks may be due to the difference of electron donating capacity of the ligands.

\section{3. Description of Structures}

The perspective view of complexes $\mathbf{1}$ and $\mathbf{2}$ together with the atom numbering scheme are shown in Figures 1 and 2 , respectively. The coordination geometry around the molybdenum(VI) atom in the complexes reveals a distorted octahedral environment with $\mathrm{NO}_{5}$ chromophore. The aroylhydrazone Schiff base behaves as dianionic tridentate ligand binding through the phenolate oxygen, the enolate oxygen and the imine nitrogen, and occupies three positions in the equatorial plane. One oxo group is located trans to the imine nitrogen in the equatorial plane. The other oxo group and the methanol oxygen are located at the axial positions. The two terminal oxo groups are hence $c i s$ to each other and exhibit typical $\mathrm{Mo}=\mathrm{O}$ double bond distances. ${ }^{12}$ The chelate rings are fused along Mo1-N1 bonds. The molybdenum is found to be deviated from the mean equatorial plane defined by the four donor atoms by 0.311(1) $\AA$ for $\mathbf{1}$ and $0.314(1) \AA$ for 2 . The Mo- $\mathrm{O}_{\text {methanol }}$ bond lengths in the complexes are longer than the normal single bond lengths (2.31-2.33 $\AA$ against 1.9-2.0 $)$ ). This shows that the methanol molecule is loosely attached to the $\mathrm{Mo}(\mathrm{VI})$ center. $^{10 \mathrm{~b}}$ The remaining Mo-O bond lengths are similar to other molybdenum(VI) complexes. ${ }^{13}$ The bond between Mo and the azomethine nitrogen in complexes $\mathbf{1}$ and $\mathbf{2}$ are 2.262(4) $\AA$ and 2.257(3) $\AA$, respectively, which is comparatively longer than the normal Mo-N single bonds. This is due to the trans effect generated by the oxo group trans to the Mo-N bond. ${ }^{9 \mathrm{~b}}$ The $\mathrm{C}(8)-\mathrm{O}(2)$ bond lengths in the complexes are $1.30-1.32 \AA$, which correspond to single bond length of the $\mathrm{C}_{\mathrm{Ar}}-\mathrm{OH}$ type. However, the shorter length compared to $\mathrm{C}-\mathrm{O}$ single bond may be attributed to extended electron delocalization in the ligands. ${ }^{9 b}$ Similarly shortening of $\mathrm{C}(8)-\mathrm{N}(2)$ bond length (1.31 $\AA$ instead of normal $1.38 \AA$ ) together with the elon-

Table 3. Hydrogen Bonding for the Complexes

\begin{tabular}{|c|c|c|c|c|}
\hline$\overline{D-H} \cdots A$ & $d(D-\mathbf{H})(\AA)$ & $d(\mathbf{H} \cdots A)(\AA)$ & $d(D \cdots A)(\AA)$ & $\operatorname{Angle}(D-H \cdots A)\left({ }^{\circ}\right)$ \\
\hline \multicolumn{5}{|l|}{1} \\
\hline $\mathrm{O} 3-\mathrm{H} 3 \cdots \mathrm{N} 2^{\mathrm{i}}$ & $0.85(1)$ & $2.00(2)$ & $2.836(5)$ & $167(7)$ \\
\hline C6-H6 $\cdots O 4^{\mathrm{ii}}$ & 0.93 & $2.49(2)$ & $3.359(5)$ & $157(6)$ \\
\hline $\mathrm{C} 7-\mathrm{H} 7 \cdots \mathrm{O} 5^{\mathrm{iii}}$ & 0.93 & $2.55(2)$ & $3.119(5)$ & $120(6)$ \\
\hline C19-H19B $\cdots$ O $^{\text {iv }}$ & 0.96 & $2.46(3)$ & $3.279(6)$ & $143(6)$ \\
\hline \multicolumn{5}{|l|}{2} \\
\hline $\mathrm{O} 4-\mathrm{H} 4 \cdots \mathrm{N} 2^{\mathrm{v}}$ & $0.85(1)$ & $1.99(2)$ & $2.826(4)$ & $169(5)$ \\
\hline 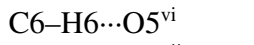 & 0.93 & $2.46(3)$ & $3.331(5)$ & $156(5)$ \\
\hline $\mathrm{C} 7-\mathrm{H} 7 \cdots \mathrm{O} 3^{\mathrm{vii}}$ & 0.93 & $2.52(3)$ & $3.091(5)$ & $120(6)$ \\
\hline $\mathrm{C} 16-\mathrm{H} 16 \mathrm{~B} \cdots \mathrm{O} 3^{\mathrm{viii}}$ & 0.96 & $2.49(3)$ & $3.286(5)$ & $140(5)$ \\
\hline
\end{tabular}

Symmetry codes: (i) $1-x,-y,-z$; (ii) $x, 1 / 2-y,-1 / 2+z$; (iii) $1-x, 1-y,-z$; (iv) $x,-1+y, z$; (v) $2-x, 1-y, 1-z$; (vi) $x, 3 / 2-y,-1 / 2+z$; (vii) $-x, 1-y,-z ;$ (viii) $x, 1+y, z$. 
gation of $\mathrm{N}(1)-\mathrm{N}(2)$ bond length also supports the electron cloud delocalization in the ligand system. ${ }^{9 \mathrm{~b}}$ The aroylhydrazone Schiff base ligand forms a five-membered and a six-membered chelate rings with the Mo center. The dihedral angle between the two phenyl rings is $6.8(3)^{\circ}$ for 1 and $5.9(5)^{\circ}$ for 2 . The trans angles between the donor atom of the methanol ligand and the oxo atom are $169.57(15)^{\circ}$ for $\mathbf{1}$ and $169.78(13)^{\circ}$ for $\mathbf{2}$, indicating considerable distortion of the coordination octahedron around the $\mathrm{Mo}(\mathrm{VI})$ center. It is usually that $-\mathrm{Cl}$ and $-\mathrm{Br}$ analogous derivatives perform isostructurality in the solid-state due

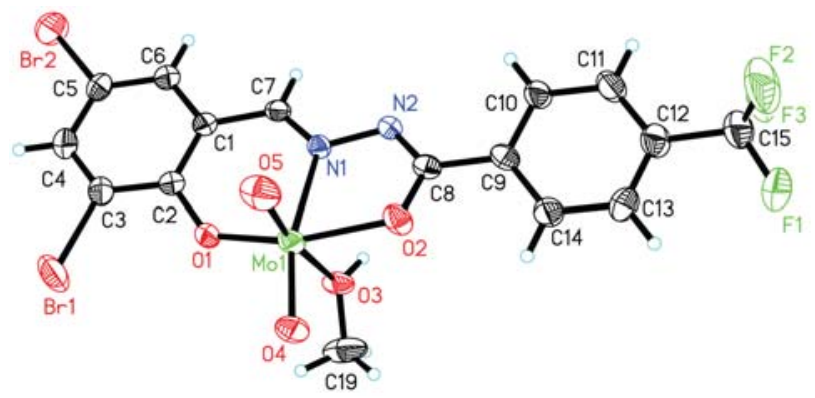

Figure 1. ORTEP plots (30\% probability level) and numbering scheme for $\mathbf{1}$.

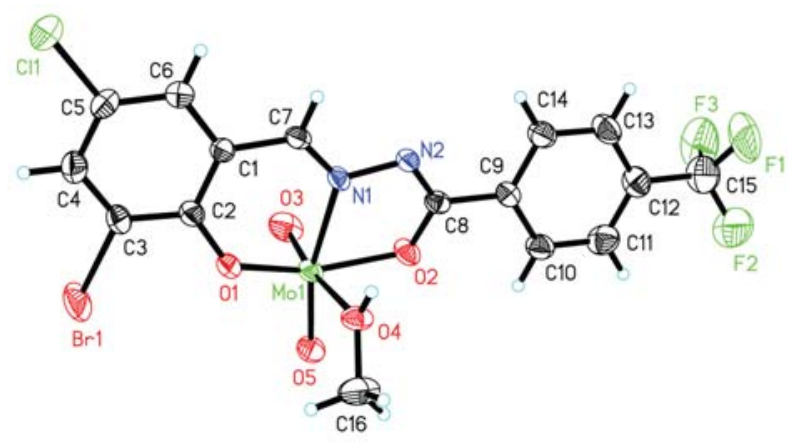

Figure 2. ORTEP plots (30\% probability level) and numbering scheme for 2 .

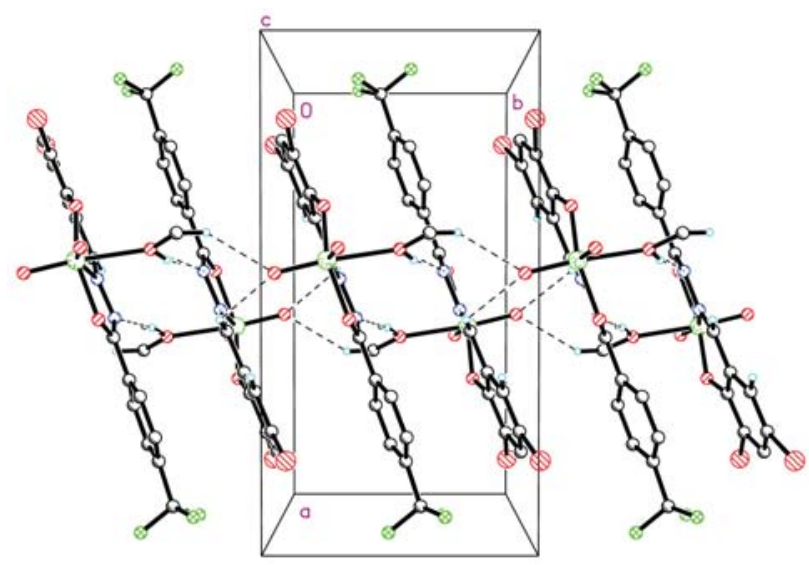

Figure 3. Hydrogen bond (dashed lines) linked structure of 1, viewed down the $c$ axis.

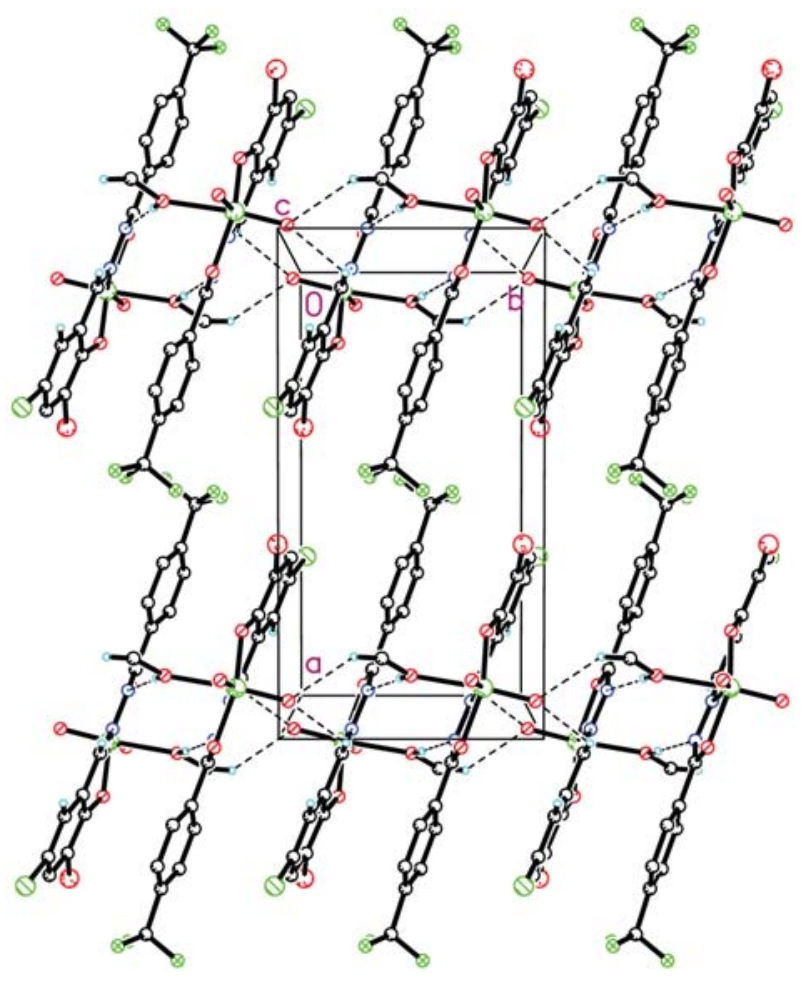

Figure 4. Hydrogen bond (dashed lines) linked structure of 2, viewed down the $c$ axis.

to similar unit cell parameteres and moreover analogous crystal packings motifs.

The crystal packing diagrams of the complexes are quite similar (Figure 3 and Figure 4). The two adjacent complex molecules are linked by two $\mathrm{O}-\mathrm{H} \cdots \mathrm{N}$ hydrogen bonds (Table 3), to form dimer. The dimers are further linked through intermolecular hydrogen bonds of $\mathrm{C}-\mathrm{H} \cdots \mathrm{O}$, to form one-dimensional chains running along $b$ axis.

\section{4. Catalytic Epoxidation Results}

Before addition of aqueous TBHP at $80{ }^{\circ} \mathrm{C}$, the molybdenum complexes dissolve completely in the organic phase. The aqueous phase of the solution was colorless and the organic phase was yellowish, indicating that the catalyst is mainly confined in the organic phase. TBHP is mainly transferred into the organic phase under those conditions, and for that reason the reactant and products in the organic layer were analyzed. Cyclooctene and cyclooctene oxide are not significantly soluble in water, therefore the determination of the epoxide selectivity (epoxide formation/cyclooctene conversion) is expected to be accurate. The obtained results are given in Table 4 . For the cyclooctene epoxidation by using aqueous TBHP, with no extra addition of organic solvents, the present study shows effective activity. Kinetic profiles of the molybdenum complexes as catalysts are presented in $\mathrm{Fi}-$ gure 5. No induction time was observed. The cyclooctene conversion for the molybdenum complexes is high after 5 
Table 4. Catalytic Results for the Cyclooctene Epoxidation by Aqueous TBHP ${ }^{\mathrm{a}}$

\begin{tabular}{lcccc}
\hline Catalyst & $\begin{array}{c}\text { Conversion } \\
(\boldsymbol{\%})^{\mathbf{b}}\end{array}$ & $\begin{array}{c}\text { Selectivity } \\
(\boldsymbol{\%})^{\mathbf{c}}\end{array}$ & $\begin{array}{c}\text { TOF } \\
\left.\mathbf{( h}^{\mathbf{- 1}}\right)^{\mathbf{d}}\end{array}$ & $\mathbf{T O N}^{\mathbf{e}}$ \\
\hline $\mathbf{1}$ & 87 & 55 & 362 & 377 \\
$\mathbf{2}$ & 85 & 56 & 365 & 382 \\
{$\left[\mathrm{MoO}_{2}(\mathrm{acac})_{2}\right]$} & 73 & 82 & 387 & 405 \\
\hline
\end{tabular}

${ }^{\text {a }}$ Reaction conditions: time, $5 \mathrm{~h}$; temperature, $80{ }^{\circ} \mathrm{C}$. Molybdenum complex/cyclooctene/TBHP molar ratio: 0.25/100/200. ${ }^{\mathrm{b}}$ For cyclooctene, calculated after $5 \mathrm{~h}$. ${ }^{\mathrm{c}}$ Formed epoxide per converted olefin after $5 \mathrm{~h} .{ }^{\mathrm{d}} n$ (cyclooctene transformed) $/ n$ (catalyst)/time at 20 minutes. ${ }^{\mathrm{e}} n$ (cyclooctene transformed) $/ n$ (catalyst at $5 \mathrm{~h}$ ).

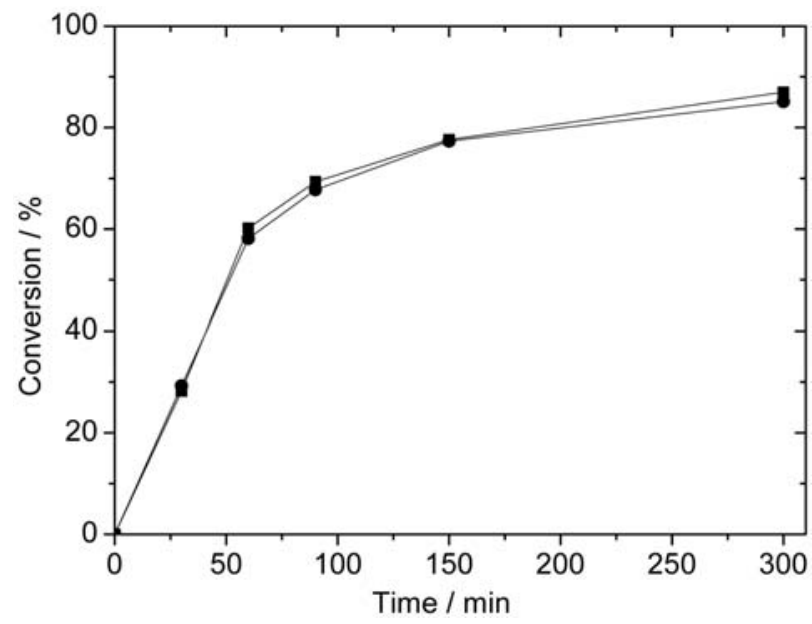

Figure 5. Kinetic monitoring of cis-cyclooctene epoxidation with TBHP- $\mathrm{H}_{2} \mathrm{O}$ in the presence of the molybdenum complexes. $\bullet$ represents $\mathbf{1}, \mathbf{-}$ represents $\mathbf{2}$.

h, viz. $87 \%$ for $\mathbf{1}$ and $85 \%$ for $\mathbf{2}$. A negative control experiment using $\left[\mathrm{MoO}_{2}(\mathrm{acac})_{2}\right]$ as catalyst has been performed for comparison. The cyclooctene conversion for
$\left[\mathrm{MoO}_{2}(\mathrm{acac})_{2}\right]$ is lower than the complexes, however, the selectivity is higher than the complexes. The usage of Mn$\mathrm{O}_{2}$ is to decompose of excessive tert-butyl hydroperoxide. $\mathrm{MnO}_{2}$ itself cannot oxidize cyclooctene to epoxycyclooctane.

Possible mechanistic consideration involves coordination of TBHP as a neutral molecule, with the hydrogen bond $\mathrm{O}-\mathrm{H} \cdots \mathrm{O}$ (Scheme 2). Even though high conversion of cyclooctene is observed, selectivity towards cyclooctene oxide is not high, 55\% for $\mathbf{1}$ and $56 \%$ for $\mathbf{2}$.

\section{Conclusion}

In summary, two new structurally similar cis-dioxomolybdenum(VI) complexes with tridentate aroylhydrazone ligands have been synthesized and characterized. The Mo atoms of the complexes are in octahedral coordination. The complexes can catalyze the epoxidation of cyclooctene, with high conversion but low selectivity.

\section{Supplementary Material}

CCDC numbers 1433321 and 1433322 contain the supplementary crystallographic data for the complexes $\mathbf{1}$ and 2, respectively. These data can be obtained free of charge via http://www.ccdc.cam.ac.uk/conts/retrieving.html, or from the Cambridge Crystallographic Data Center, 12, Union Road, Cambridge CB2 1EZ, UK; fax: +44 1223336 033; or e-mail: deposit@ @cdc.cam.ac.uk.

\section{Acknowledgments}

This work was financed by the National Technology Support Project (2012BAD36B03), the Open Foundation

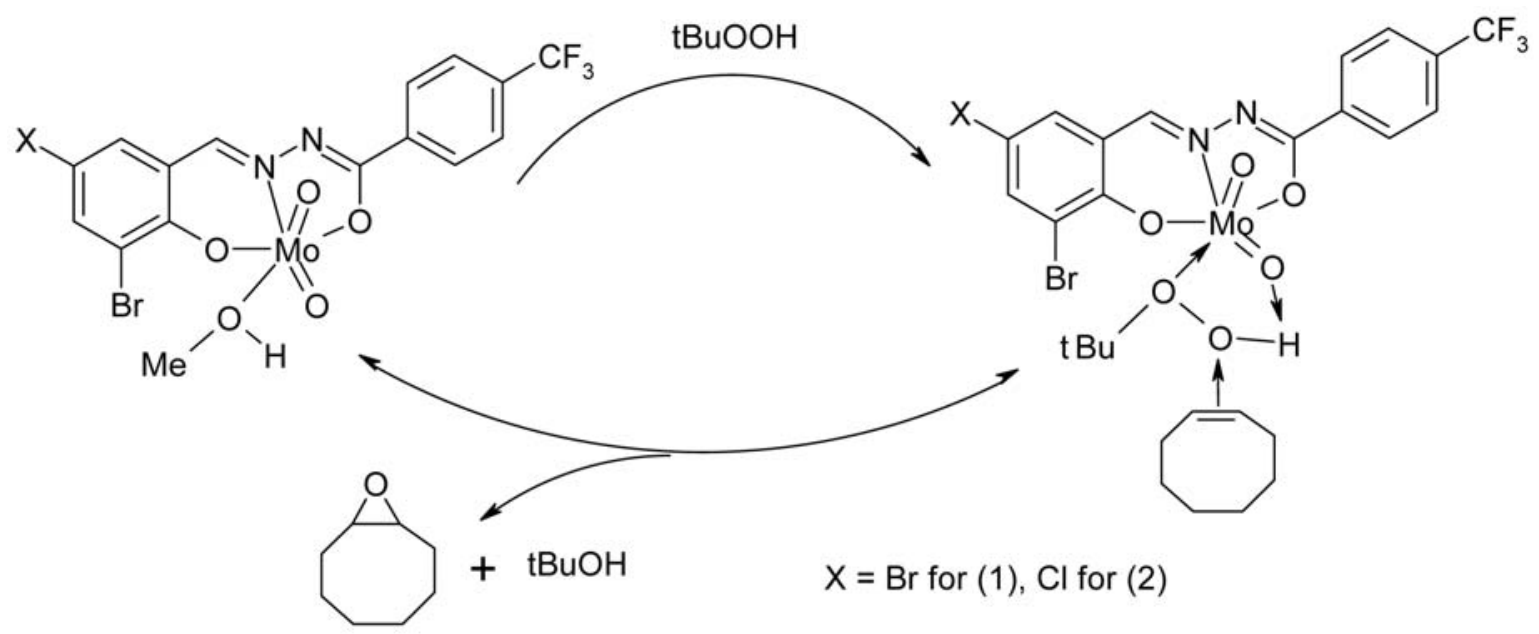

Scheme 2. Proposed mechanism for the catalytic process. 
of Zhejiang Provincial Top Key Academic Discipline of Chemical Engineering and Technology (YR2015004) and the Foundation of Wuhan Textile University.

\section{References}

1. (a) M. C. Heffern, V. Reichova, J. L. Coomes, A. S. Harney, E. A. Bajema, T. J. Meade, Inorg. Chem. 2015, 54, 90669074; http://dx.doi.org/10.1021/acs.inorgchem.5b01415

(b) S. Meghdadi, M. Amirnasr, M. Majedi, M. Bagheri, A. Amiri, S. Abbasi, K. Mereiter, Inorg. Chim. Acta 2015, 437, 64-69; http://dx.doi.org/10.1016/j.ica.2015.08.006

(c) D. Qu, F. Niu, X. Zhao, K.-X. Yan, Y.-T. Ye, J. Wang, M. Zhang, Z. You, Bioorg. Med. Chem. 2015, 23, 1944-1949; http://dx.doi.org/10.1016/j.bmc.2015.03.036

(d) H. Zafar, A. Ahmad, A. U. Khan, T. A. Khan, J. Mol. Struct. 2015, 1097, 129-135;

http://dx.doi.org/10.1016/j.molstruc.2015.04.034

(e) X. Zhao, X. Chen, J. Li, J. Chen, G. Sheng, F. Niu, D. Qu, Y. Huo, H. Zhu, Z. You, Polyhedron 2015, 97, 268-272. http://dx.doi.org/10.1016/j.poly.2015.07.012

2. (a) K.-H. Yang, Acta Chim. Slov. 2014, 61, 629-636; (b) S.S. Qian, X. Zhao, J. Wang, Z. You, Acta Chim. Slov. 2015, 62, 828-833; (c) L.-X. Li, Y. Sun, Q. Xie, Y.-B. Sun, K.-H. Li, W. Li, Z.-L. You, Chinese J. Inorg. Chem. 2016, 32, 369-376;

(d) X. Zhao, X. Chen, J. Li, J. Chen, G. Sheng, F. Niu, D. Qu, Y. Huo, H. Zhu, Z. You, Polyhedron, 2015, 97, 268-272. http://dx.doi.org/10.1016/j.poly.2015.07.012

3. (a) R. G. Mohamed, F. M. Elantabli, N. H. Helal, S. M. ElMedani, Synth. React. Inorg. Met.-Org. Nano-Met. Chem. 2015, 45, 1839-1850;

(b) T. S. M. Oliveira, A. C. Gomes, A. D. Lopes, J. P. Lourenco, F. A. A. Paz, M. Pillinger, I. S. Goncalves, Dalton Trans. 2015, 44, 14139-14148;

http://dx.doi.org/10.1039/C5DT02165K

(c) C. A. Koellner, N. A. Piro, W. S. Kassel, C. R. Goldsmith, C. R. Graves, Inorg. Chem. 2015, 54, 7139-7141; http://dx.doi.org/10.1021/acs.inorgchem.5b01136 (d) T. Alemohammad, N. Safari, S. Rayati, M. Gheidi, A. Mortazavimanesh, H. Khavasi, Inorg. Chim. Acta 2015, 434, 198-208; http://dx.doi.org/10.1016/j.ica.2015.05.023

(e) M. Bagherzadeh, A. Ghanbarpour, H. R. Khavasi, Catal. Commun. 2015, 65, 72-75.

http://dx.doi.org/10.1016/j.catcom.2015.02.023

4. (a) H. Y. Liu, L. Q. Zang, J. L. Lv, Russ. J. Coord. Chem. 2015, 41, 451-455; http://dx.doi.org/10.1134/S1070328415070052

(b) S. Morales-delaRosa, J. M. Campos-Martin, P. Terreros, J. L. G. Fierro, Topics in Catal. 2015, 58, 325-333; http://dx.doi.org/10.1007/s11244-015-0373-1

(c) T. Baskaran, R. Kumaravel, J. Christopher, T. G. Ajithkumar, A. Sakthivel, New J. Chem. 2015, 39, 3758-3764. http://dx.doi.org/10.1039/C4NJ02402H

5. M. Amir, K. Shikha, Eur. J. Med. Chem. 2004, 39, 535-545. http://dx.doi.org/10.1016/j.ejmech.2004.02.008

6. G. J. J. Chen, J. W. McDonald, W. E. Newton, Inorg. Chem. 1976, 15, 2612-2615. http://dx.doi.org/10.1021/ic50165a008

7. (a) G. M. Sheldrick, SADABS, Siemens Analytical X-ray Instrument Division: Madison, WI, 1995; (b) G. M. Sheldrick, SHELXS97 Program for solution of crystal structures, University of Göttingen, Germany, 1997.

8. (a) Y.-T. Ye, F. Niu, Y. Sun, D. Qu, X.-L. Zhao, J. Wang, D.M. Xian, J. Hauser, Z.-L. You, Chinese J. Inorg. Chem. 2015, 31, 1019-1026;

(b) Z.-L. You, D.-M. Xian, M. Zhang. CrystEngComm 2012, 14, 7133-7136. http://dx.doi.org/10.1039/c2ce26201k

9. (a) R. A. Lal, M. Chakrabarty, S. Choudhury, A. Ahmed, R. Borthakur, A. Kumar, J. Coord. Chem. 2010, 63, 163-175; http://dx.doi.org/10.1080/00958970903259451

(b) T. Glowiak, L. Jerzykiewicz, J. M. Sobczak, J. J. Ziolkowski, Inorg. Chim. Acta 2003, 356, 387-392. http://dx.doi.org/10.1016/S0020-1693(03)00301-3

10. (a) R. Hahn, U. Kusthardt, W. Scherer, Inorg. Chim. Acta 1993, 210, 177-182; http://dx.doi.org/10.1016/S0020-1693(00)83325-3 (b) S. Gupta, A. K. Barik, S. Pal, A. Hazra, S. Roy, R. J. Butcher, S. K. Kar, Polyhedron 2007, 26, 133-141. http://dx.doi.org/10.1016/j.poly.2006.08.001

11. (a) L.-X. Li, Y. Sun, Q. Xie, Y.-B. Sun, K.-H. Li, W. Li, Z.-L. You, Chinese J. Inorg. Chem. 2016, 32, 369-376;

(b) L. Pan, C. Wang, K. Yan, K. Zhao, G. Sheng, H. Zhu, X. Zhao, D. Qu, F. Niu, Z. You, J. Inorg. Biochem. 2016, 159, 22-28; http://dx.doi.org/10.1016/j.jinorgbio.2016.02.017 (c) D. Qu, F. Niu, X. Zhao, K.-X. Yan, Y.-T. Ye, J. Wang, M. Zhang, Z. You, Bioorg. Med. Chem. 2015, 23, 1944-1949. http://dx.doi.org/10.1016/j.bmc.2015.03.036

12. (a) M. Bagherzadeh, M. Amini, H. Parastar, M. Jalali-Heravi, A. Ellern, L. K. Woo, Inorg. Chem Commun. 2012, 20, 86-89; http://dx.doi.org/10.1016/j.inoche.2012.02.023

(b) R. Dinda, P. Sengupta, S. Ghosh, H. Mayer-Figge, W. S. Sheldrick, J. Chem. Soc. Dalton Trans. 2002, 23, 44344439. http://dx.doi.org/10.1039/b207129k

13. (a) R. Dinda, S. Ghosh, L. R. Falvello, M. Tomas, T. C. W. Mak, Polyhedron 2006, 25, 2375-2382; http://dx.doi.org/10.1016/j.poly.2006.02.002 (b) V. Vrdoljak, B. Prugovečki, D. Matković-Čalogović, J. Pisk, R. Dreos, P. Siega, Cryst. Growth Des. 2011, 11, 12441252. http://dx.doi.org/10.1021/cg1014576 


\section{Povzetek}

Sintetizirali smo dva nova cis-dioksomolibdenova(VI) kompleksa s splošno formulo $\left[\mathrm{MoO}_{2} \mathrm{~L}(\mathrm{MeOH})\right]$, kjer je $\mathrm{L}=\mathrm{L}^{1}=$ $N^{\prime}$-(3,5-dibromo-2-hidroksibenziliden)-4-trifluorometilbenzohidrazid (1) oziroma $\mathrm{L}=\mathrm{L}^{2}=N^{\prime}$-(3-bromo-5-kloro-2hidroksibenziliden)-4-trifluorometilbenzohidrazid (2) ter ju okarakterizirali z elementno analizo, FT-IR, molsko prevodnostjo in UV-Vis spektroskopijo. Kompleksa sta bila strukturo okarakterizirana tudi z monokristalno rentgensko difrakcijo. Kompleksa imata popačeno oktaedrično strukturo z aroilhidrazonom kot dianionskim ligandom. Iz kristalne strukture je razvidno, da ima $\mathrm{Mo}(\mathrm{VI})$ center $\mathrm{NO}_{5}$ donorsko okolje ter da sta del oktaedrične strukture dve oksido skupini in atom kisika iz molekule metanola. Katalitične lastnosti so bile raziskane na primeru epoksidacije ciklooktena z uporabo vodne raztopine terc-butil hidroperoksida kot oksidanta. 